\title{
Stock options and managerial incentives to invest
}

Tom Nohel and Steven Todd*

First Version: February 8, 2000

This Version: November 9, 2001

Tom Nohel is an Associate Professor of Finance at Loyola University - Chicago. Steven Todd is an Assistant Professor of Finance at Loyola University - Chicago. We would like to thank Greg Chaudoin and Tim Kruse for their comments. We are especially grateful to Lu Hong for many helpful discussions and suggestions. All remaining errors are the responsibility of the authors. A previous version of this paper was titled "Executive compensation, reputation and risk-taking incentives."

Address correspondence to: Steven Todd, Department of Finance, School of Business Administration, Loyola University Chicago, 820 N. Michigan Avenue, Chicago, IL 60611 (Office: 312-915-7218; Fax: 312-915-8508; email: stodd@luc.edu) 


\title{
Stock options and managerial incentives to invest
}

\begin{abstract}
We examine the effect of stock options on managerial incentives to invest. Our chief innovation is a model wherein firm value and executive decisions are endogenous. Numerical solutions to our model show that managerial incentives to invest are multi-dimensional and highly sensitive to option strike prices, the manager's wealth, degree of diversification, risk aversion, and career concerns. We find that over-investment problems are far more likely and far more severe than many researchers suggest. Finally, firm value is not a strictly increasing function of a manager's incentive compensation or conventional pay-for-performance metrics. Stronger managerial incentives to invest can benefit or harm a firm. Our results should send a cautionary signal to researchers who study managerial behavior. It is not sufficient to rely on one-dimensional risk-neutral valuation metrics, such as pay-forperformance, to describe the degree of incentive alignment between managers and shareholders.
\end{abstract}

JEL Classification: G31, G34, J33, L22. 


\section{Introduction}

Researchers looking to examine the incentive effects of executive stock options are confronted with two immediate challenges. First, standard Black-Scholes risk-neutral valuation techniques are inaccurate because executive stock options are not traded, and they are frequently held by managers with undiversified wealth (including human capital) facing short-sale and liquidity constraints. Second, option values are inextricably linked to executive actions and firm value. If options didn't affect managerial behavior, and if managerial behavior didn't affect firm value, then why would firms choose to grant options? The fact that options are a large and growing portion of U.S. executive pay (Murphy, 1999), that firms routinely re-price stock options (Brenner, Sundaram and Yermack, 2000), that largely as a result of stock option pay, U.S. executives, on average, hold a claim on more than $3 \%$ of their firms' shares (Conyon and Murphy, 2000), - all these facts suggest that the agency problems between managers and shareholders are large and that the benefits of stock option compensation are potentially great.

This paper examines the effect of stock options on managerial incentives to invest. We extend the literature by studying this effect within a model that links executive actions and firm value. This is important. Managers have direct control over their firm's financing and investment decisions. And stock options are a mechanism to alter managerial behavior so that shareholder and executive interests are aligned to maximize firm value.

The value and incentive effects of executive stock options depend on the parameters of the option contract, and the manager's wealth, degree of diversification, and risk aversion (Lambert, Larcker and Verrechia, 1991). We construct a model of managerial investment that links firm value to managerial behavior, and managerial behavior to executive-specific risk and wealth parameters. One advantage of our approach is that we are able to describe managerial incentives to invest as hurdle 
rates, rather than partial derivatives of the manager's utility function (Hall and Murphy, 2000) or comparative statics from a Black-Scholes option pricing model (Johnson and Tian, 2000). These hurdle rates allow us to quantify the degree of under- or over-investment in simple terms.

In our model, a risk-averse executive sets the investment strategy of his firm based on private information he possesses about project payoffs. We assume the executive maximizes the expected utility of his future wealth. His wealth includes cash, and incentive compensation in the form of shares and options on his firm's shares; it also includes a measure of his human capital - the value of his expected future compensation, which itself is a function of the manager's perceived ability. We assume the value of the manager's human capital rises and falls with the value of the firm he manages. Since the manager is risk averse, he overweighs the downside risk to the value of his human capital. When the manager is reluctant to put his human capital at risk we say he has "career concerns." Career concerns create an agency problem between the executive and the risk-neutral owners of the firm: the executive ignores investors' risk-return preferences and maximizes his own utility (see Holmstrom and Ricart i Costa (1986), Milgrom and Roberts (1992) and Nohel and Todd (2001). We analyze how the executive's choices change as the parameters of his wealth and compensation vary.

Our analysis produces some interesting results. First, we find that executive incentives to invest are highly sensitive to the distribution of managerial wealth and the magnitude of executive career concerns. Using reasonable values for these parameters, we show that under- and overinvestment problems can be large and economically significant, with hurdle rates ranging from more than 20 percentage points below to more than 35 percentage points above shareholders' required rate of return. The likelihood and severity of over-investment problems are greater than some researchers suggest (see Aggarwal and Samwick, 1999; Guay, 1999; and Lambert et al., 1991).

Second, we find that incentive alignment is possible, there are a variety of ways to achieve 
incentive alignment, and that depending on investment risks and executive-specific risk and wealth parameters, stock options can be a small or large component of executive pay.

Third, contrary to Hall and Murphy (2000), we find that managerial incentives to invest are highly sensitive to stock option strike prices. Even when options constitute only $10 \%$ of an executive's wealth, a 10\% change in the option strike price can move the manager's hurdle rate up or down by more than 9 percentage points. In our model, at-the-money options maximize a manager's incentive to take risk. However, in many situations, premium options do a better job of aligning executive and shareholder interests, a point made in Johnson and Tian (2000). The relation between option strike prices and managerial investment incentives has important implications for the issue of stock option re-pricing.

Fourth, we argue that if incentive alignment were the primary rationale for the use of stock options by corporations, we would expect to see frequent option re-pricing both when stock prices fall and when they rise. In contrast, Brenner, Sundaram and Yermack (2000) find that nearly all repricing occurs after a fall in stock prices. We would also expect corporations to monitor executive wealth, possibly restricting executive share holdings, which discourage risk-taking and counteract the desired effects of stock options.

Finally, we find that the comparative statics from risk-neutral option valuation models (e.g., Black-Scholes) do not provide accurate guideposts for the magnitude of managerial incentives to invest. Our results indicate that a risk-averse manager who cannot diversify the risk associated with his stock option wealth may not prefer an increase in the value of his firm's stock or the variance of his firm's stock returns. Furthermore, using pay-for-performance measures to describe the degree of alignment between managers and shareholders is problematic, since managerial incentives to increase firm value do not necessarily rise as the manager's pay becomes more sensitive to performance. 
Empirical studies of managerial behavior that focus on one dimension of compensation and ignore managerial differences in wealth and risk preferences may introduce measurement error problems that generate misleading inferences. Our results are relevant to studies that examine the relation between executive compensation and corporate investment decisions, such as Aggarwal and Samwick (1999), and Datta, Iskandar-Datta, and Raman (2000). Our results can also inform studies of ownership structure and firm performance, such as Demsetz and Villalonga (2000), Himmelberg, Hubbard and Palia (1999), and Ljungqvist and Habib (2000).

The remainder of this paper is organized as follows. We develop a model of managerial investment in Section 2 and solve the model numerically for a variety of parameterizations in Section 3. We discuss pay-for-performance and firm value in Section 4 and conclude in Section 5.

\section{A Model of Managerial Investment}

In this section, we model the investment behavior of a risk-averse manager whose wealth consists of cash and incentive compensation in the form of shares, and call options on his firm's shares. We assume the manager maximizes the expected utility of his future wealth, which includes not only cash and incentive compensation, but also a measure of his human capital - the expected value of his future compensation that is based on his perceived ability. ${ }^{1}$ The manager sets his firm's investment strategy based on private information he possesses about project payoffs. One salient feature of our model is that firm value is a function of managerial behavior and managerial behavior is a function of executive wealth.

1 The compensation a manager can expect to earn over his career depends on his reputation. In our model, reputation is not something that the manager can cultivate, say, by working harder. 


\subsection{Set-up and Information Structure of the Model}

Consider a firm with $I$ dollars in cash on its balance sheet at $\mathrm{t}=0$. The firm's investment opportunity set consists of two mutually exclusive projects. Each project requires an initial investment of $I$. One project is riskless and thus earns the risk-free rate, which we set equal to 0 for ease of exposition. The other project is risky and generates a payoff that is uniformly distributed on the interval, $\left[V_{L}, V_{H}\right]$, with $V_{H} \geq I \geq V_{L}$. The low end of the distribution, $V_{L}$, is known and certain. The high end, $V_{H}$, is uncertain but known to be uniformly distributed on the interval, $\left[V_{H l}, V_{H 2}\right]$. Assume the relationship among $I, V_{L}, V_{H 1}$, and $V_{H 2}$ is such that $I=\left(V_{L}+\left(V_{H I}+V_{H 2}\right) / 2\right) / 2 .^{2}$

Our model has three types of participants: investors, a manager, and an intermediary. Investors put their capital at risk in the firm. They select an intermediary to hire a manager and design the manager's compensation. Think of this intermediary as either a compensation consultant or the firm's board of directors. For ease of exposition, we refer to the intermediary as the board of directors, or simply the board. We assume the board acts in the interest of shareholders and is otherwise passive. The manager makes the firm's investment decisions.

The timing in our model is as follows: at $\mathrm{t}=0$, investors know that the firm has $I$ in cash on its balance sheet. Furthermore, at $\mathrm{t}=0$, investors are aware of the firm's investment opportunities (including the distribution of project payoffs) and they elect a board of directors to hire a manager of unknown talent. The board fixes a compensation budget for the manager and sets the terms of his compensation. At $\mathrm{t}=0+$, the board hires a manager and pays him. His pay consists of a cash salary, and incentive compensation in the form of shares and options on his firm's shares. At $t=1$, the manager receives a signal that identifies $V_{H}$. Think of this signal as a measure of the manager's talent.

\footnotetext{
2 That is, ex-ante, both the riskless and the risky projects have zero NPV. This assumption is consistent with strongform market efficiency. However, as long as $V_{H I} \geq I \geq V_{L}$, most of our results hold.
} 
Based on this signal, the manager chooses between the firm's two investment opportunities. The signal is never revealed and thus cannot be contracted on. At $t=2$, the outcome of the investment decision is realized, the manager's shares and options vest, and the firm is liquidated. ${ }^{3}$ Below is a time line specifying critical events in our model:

\begin{tabular}{|c|c|c|c|}
\hline $\begin{array}{l}\text { Investors elect } \\
\text { board and set } \\
\text { comp. budget }\end{array}$ & $\begin{array}{l}\text { Designer hires mgr., } \\
\text { reveals contract } \\
\& \text { inv. opps }\end{array}$ & $\begin{array}{l}\text { Manager gets private } \\
\text { signal and invests }\end{array}$ & $\begin{array}{l}\text { Project payoffs determined, } \\
\text { shares \& options vest, and } \\
\text { the firm is liquidated }\end{array}$ \\
\hline$=0$ & $\mathbf{t}=\mathbf{0}+$ & $t=1$ & $t=2$ \\
\hline
\end{tabular}

Investors and the manager differ in their preferences towards risk. We assume investors are risk-neutral and the manager is risk-averse in wealth. This assumption is consistent with Hemmer, Matsunaga, and Shevlin (1996) who find that executives exercise their stock options early. We further assume the manager's utility function exhibits constant relative risk-aversion as described below. ${ }^{4}$

$$
U(w)=\frac{1}{1-b} w^{(1-b)}, b \geq 0, b \neq 1
$$

Here, $w$ is the level of the manager's wealth that he derives from the following sources: cash (including salary and non-firm wealth), incentive compensation (shares and options on his firm's shares), and the change in the value of the manager's human capital. ${ }^{5}$

Let $\mathrm{K}$ denote the value of the manager's cash wealth. The manager's incentive compensation includes $n$ shares, and $m$ options with an exercise price of $X$. Here $n$ and $m$ represent fractions of the

3 The distribution of project outcomes and the information structure of our model are similar to Ross (1977). The binary nature of the investment choice is common in the literature. See, for example, John and John (1993), Lambert (1986), and Holmstrom and Ricart i Costa (1986).

$4 \quad$ The conclusions of our paper are valid with any utility function that exhibits decreasing absolute risk aversion. We chose the specification above since it is common in the literature; see Lambert, et al. (1991) and Hall and Murphy (2000).

5 In the interests of simplicity, we model the manager's risky security holdings as cash equivalents. For a similar treatment, see Lambert, et al. (1991) and Hall and Murphy (2000). 
shares outstanding in the manager's firm. We restrict $K, n$, and $m$ to be non-negative and we assume shares and options vest at $\mathrm{t}=2 .^{6}$

We assume the manager's ability is a random draw. The manager receives a signal about his ability before he chooses his firm's investment strategy. Shareholders cannot measure the manager's ability. Instead they infer it based on the manager's performance.

We assume the manager's performance affects his expected future income, i.e., the value of his human capital. Since the manager is risk averse, he overweighs the downside risk to the value of his human capital. These "career concerns" create an agency problem between the manager and the risk-neutral owners of the firm he manages (see also Holmstrom and Ricart i Costa, 1986; Milgrom and Roberts, 1992; and Nohel and Todd, 2001). ${ }^{7}$

Fee and Hadlock (2001) show that stock returns are used as a performance metric by the external labor market for top-ranked executives, and Jagannathan and Wang (1996) show that stock returns are linearly related to the return on human capital. Consistent with these results, we assume the value of the manager's human capital is linear in firm value. ${ }^{8}$ Specifically, we assume the change in the value of the manager's human capital is proportional to the change in firm value from the time when the manager is hired $(t=0+)$, to the time when the firm is liquidated $(t=2)$. If $\alpha$ is a nonnegative constant, $V$ is the firm's liquidation value, and $V_{0+}$ is the value of the firm immediately after

\footnotetext{
6 In the interests of simplicity, we sidestep the more general problem of an executive who has a portfolio of options with varying strike prices.

$7 \quad$ We side-step the common assumption of managerial dis-utility of effort. The notion that a manager can positively affect output by working harder but prefers not to is inconsistent with the behavior of top-level executives. Kaplan (1984) points out that contemporary managers often work too hard rather than too little. It is hard to conceive of managers shirking, given continual monitoring by the financial press and securities analysts. Allen (2001) suggests that instead of modeling effort aversion, research in this area should focus on implicit contracts and reputation. He considers the financial industry, but his remarks apply to any situation where, as he says, "the principal does not have the expertise that the agent does."
}

This mirrors Graham (1999) who assumes that analysts' wages increase linearly with their reputations. 
the manager is hired, then the change in the value of the manager's human capital is $\alpha\left(V-V_{0+}\right)$. Note that with this specification, the expected change in the value of the manager's human capital is zero. Intuitively, we interpret the change in the value of the manager's human capital as the present value of all future compensation gains (losses) that are attributable to the manager's performance.

Investors are rational so the firm's value changes as new information is released. Starting at an initial value of I (at time 0 ), the firm's value adjusts sequentially to reflect information about the hiring of the manager (time $0+$ ), the manager's investment decision (time 1), and the final project outcome (time 2). The price adjustment from time 0 to time $0+$ reflects investors' valuation of the marginal benefit/cost of hiring the manager, and is consistent with investor reactions to awards of incentive pay, as documented in Defusco, Johnson, and Zorn (1990) and Yermack (1997). Note that since the firm's value is $I$ just prior to the manager being hired, options with strike prices above (below) $I$ are out-of-the-money (in-the-money). The stock price adjusts to $V_{0+}$ only after the hiring of the manager is made public.

Due to the binary nature of the investment choice in our model, an investment strategy is defined as a cut-off point. Consider any $V_{H}^{\ddagger}$, where $V_{H 2} \geq V_{H}^{\ddagger} \geq V_{H 1}$. [ $\left.V_{H}^{\ddagger}\right]$ denotes the strategy where the manager invests in the risky project whenever he observes a signal $V_{H} \geq \downarrow_{H}^{\ddagger}$; otherwise he invests in the riskless project. Thus, if the manager follows investment strategy [ $\left.V_{H}^{\ddagger}\right]$, he chooses the risky project with probability $\left(V_{H 2}-\bigvee_{H}^{\ddagger}\right) /\left(V_{H 2}-V_{H 1}\right)$, and he chooses the riskless project with probability 
$1-\frac{V_{H 2}-V_{H}^{\ddagger}}{V_{H 2}-V_{H 1}}=\frac{V_{H}^{\ddagger}-V_{H 1}}{V_{H 2}-V_{H 1}}$. By definition, the riskless project has zero NPV. In contrast, the opportunity to take the risky project has NPV equal to $\left[\left(V_{H 2}+\hat{V}_{H}\right) / 2+V_{L}\right] / 2-I .^{9}$

Therefore, if the manager follows investment strategy $\left[\hat{V}_{H}\right]$, the value of the firm after the manager is hired, $V_{0+}$, as a function of the manager's investment strategy, $\left[\hat{V}_{H}\right]$, is given by:

$$
V_{0+}\left(\hat{V}_{H}\right)=I+\frac{\left(V_{H 2}-\hat{V}_{H}\right)}{\left(V_{H 2}-V_{H 1}\right)}\left(\frac{\frac{V_{H 2}+\hat{V}_{H}}{2}+V_{L}}{2}-I\right)
$$

Equation (2) ignores the cost of the manager's compensation.

Risk-neutral shareholders strictly prefer the risky project as long as it offers an expected return that exceeds the risk-free rate of zero. This implies that their preferred investment strategy is to set $\hat{V}_{H}=2 I-V_{L}$.

The risk-averse manager with career concerns ignores investors' preferences on investment strategy and maximizes his own utility. Herein lies the agency problem. Compensate the manager in cash and he is too conservative, because a risky project entails human capital risk without sufficient reward in some states. Substituting shares for cash makes matters worse. In fact, in our model, the change in the value of a manager's human capital is equivalent to the change in the value of a long forward contract on the manager's firm's shares. When compensation is linear in firm value, the combination of the manager's risk aversion and career concerns compels the manager to follow an overly conservative investment strategy $\left[\downarrow_{H}^{\ddagger}\right]$, where $V_{H}^{\ddagger}>2 I-V_{L}$. The board of directors is faced 
with the problem of finding ways to overcome the manager's excessive conservatism by incorporating compensation elements whose values are convex in firm value. ${ }^{10}$

\subsection{Solution to the model}

The manager develops his investment strategy $\left[\hat{V}_{H}\right]$ by solving for the value of the signal that makes him indifferent between the two projects. Given wealth and compensation $(K, n, m, X)$ and a signal $V_{H}$, the manager can invest in the risky project and derive expected utility equal to:

$$
\begin{gathered}
E\left[U\left(K, n, m, X, V_{H}\right)\right]=\frac{1}{1-b}\left(\frac{1}{\left(V_{H}-V_{L}\right)}\right)\left(\int_{V_{L}}^{\operatorname{Min}\left(X, V_{H}\right)}\left(n V+K+\alpha\left(V-V_{0+}\right)\right)^{(1-b)} d V+\right. \\
\left.\int_{\operatorname{Min}\left(X, V_{H}\right)}^{V_{H}}\left(n V+m(V-X)+K+\alpha\left(V-V_{0+}\right)\right)^{(1-b)} d V\right)
\end{gathered}
$$

In this expression, $\alpha\left(V-V_{0+}\right)$ measures the change in the value of the manager's human capital. ${ }^{11}$

Alternatively, the manager can invest in the riskless project and derive (expected) utility equal to:

$$
U\left(K, n, m, X, V_{H}\right)=\frac{1}{1-b}\left[n I+\operatorname{mMax}(0, I-X)+\alpha\left(I-V_{0+}\right)+K\right]^{1-b}
$$

Here, the term $\alpha\left(I-V_{0+}\right)$ measures the change in the value of the manager's human capital.

10

One possible solution to this problem is for shareholders to insure the manager's human capital with a "bonus" that is equivalent to a short forward contract on the firm's shares. However, such a scheme is not incentive compatible because it asks the manager to return money to his firm when the value of his human capital increases. Since the manager's performance is observable, the manager can simply quit his current firm and capture the increased value of his human capital at another firm.

11 We set the integral limits equal to $\operatorname{Min}\left(X, V_{H}\right)$ rather than $X$. When the option strike price is greater than the value of the manager's signal, the options are worthless and the manager makes his investment decision based only on the value of his cash and shares. 
The manager sets his investment rule $\left[V_{H}^{\ddagger}\right.$ ], by solving for the value of $V_{H}$ that equates (3) and (4); this is the value of $V_{H}$ that solves (5):

$$
\begin{aligned}
& \frac{1}{1-b}\left(\frac{1}{\left(V_{H}-V_{L}\right)}\right) \int_{V_{L}}^{\operatorname{Min}\left(X, V_{H}\right)}\left(n V+K+\alpha\left(V-V_{0+}\right)\right)^{1-b)} d V+ \\
& \left.\int_{\operatorname{Min}\left(X, V_{H}\right)}^{V_{H}}\left(n V+m(V-X)+K+\alpha\left(V-V_{0+}\right)\right)^{1-b)} d V\right)=\frac{1}{1-b}\left[n I+\operatorname{mMax}(0, I-X)+\alpha\left(I-V_{0+}\right)+K\right]^{1-b}
\end{aligned}
$$

Let $V_{H}^{*}$ denote the value of $V_{H}$ that solves (5). If the manager acts in his own interest, he follows investment strategy, $\left[V_{H}^{*}\right]$.

\section{Wealth, incentive compensation, and managerial investment}

In this section, we report solutions to equation (5). We are interested in comparing the incentive effects of various divisions of wealth and incentive compensation $(K, n, m, X)$. We follow Johnson and Tian (2000) and Hall and Murphy (2000) and compare schemes of equal cost from the perspective of risk-neutral shareholders. $^{12}$

We set the manager's coefficient of relative risk aversion, $b=3$, consistent with studies by Friend and Blume (1975), Litzenberger and Ronn (1986), Lambert, et al. (1991) and Hall and Murphy (2000). The change in the value of the manager's human capital is given by $\alpha\left(V-V_{0+}\right)$. Since we are comparing compensation schemes of equal cost, and since the manager's utility function exhibits constant relative risk aversion, only the ratio of alpha to wealth matters. We consider a range of

12 In determining the cost of a compensation plan, we assume that the board values shares and options under shareholders' preferred investment strategy, $\$_{H}=2 I-V_{L}$. Therefore, we compute $n$ using the formula for firm value given in (2), with $\hat{V}_{H}$ set equal to $2 I-V_{L}$. We determine $m$ in an analogous way using the call option formula derived in Appendix A. For a similar treatment see Gavish and Kalay (1983). 
ratios, $\alpha / W$, from 0 to $0.6 \%$. With this range of ratios, career concerns run the gamut from slight to extreme. $^{13}$

We set $X=I$ (firm value at time 0) initially, consistent with the near uniform practice of granting options at-the-money (Murphy, 1999). ${ }^{14}$ We consider three risky projects, each requiring an initial investment of $\mathrm{I}=\$ 100$ : a low-risk project with $\left(\mathrm{V}_{\mathrm{L}}, \mathrm{V}_{\mathrm{H} 1}, \mathrm{~V}_{\mathrm{H} 2}\right)=(75,100,150)$; a medium risk project with $\left(\mathrm{V}_{\mathrm{L}}, \mathrm{V}_{\mathrm{H} 1}, \mathrm{~V}_{\mathrm{H} 2}\right)=(50,100,200)$; and a high-risk project with $\left(\mathrm{V}_{\mathrm{L}}, \mathrm{V}_{\mathrm{H} 1}, \mathrm{~V}_{\mathrm{H} 2}\right)=(25,100$, 250). As a percentage of invested capital, these projects have volatilities equal to $14.4 \%, 28.9 \%$, and $43.3 \%$ respectively, and net present values equal to $3.125 \%, 6.25 \%$, and $9.375 \%$ respectively. We believe these projects are representative of the projects available to typical U.S. firms. As Dimson and Marsh (2001) show, for the period 1955 - 1999, the geometric equity risk premium for U.S. firms is $6.2 \%$.

Tables 1-3 summarize managerial investment strategies for various divisions of wealth and incentive compensation and for a range of career concerns. To facilitate comparative analysis, we convert the manager's investment strategy $\left[V_{H}^{*}\right]$ into a hurdle rate. In all tables, shareholders' preferred hurdle rate is $0.0 \%$. Table 1 reports managerial hurdle rates for the low risk project; Tables 2 and 3 report managerial hurdle rates for the medium and high risk projects, respectively. We shade regions in the tables where over-investment occurs.

13 Other things being equal, we would expect younger (or more recently tenured) managers with less accumulated wealth to have higher career concerns (see Gibbons and Murphy, 1992). In our numerical solutions below, we consider a range of risky project cash flows. For the median CEO with effective shareholdings equal to $1.48 \%$ of his firm's shares (Conyon and Murphy, 2000), the range of career concerns we consider covers a gain/loss in human capital equal to $+37 \%$ to $-34 \%$ of total share wealth. For a CEO with smaller (larger) effective shareholdings or other wealth, the potential gain/loss in human capital covered by this range of career concerns can be considerably larger (smaller).

14 Again, note that until the manager is hired, firm value is $I$. Thus, striking the manager's options at-the-money means setting $X=I$. 
We find that managerial incentives to invest are highly sensitive to the distribution of wealth and the magnitude of executive career concerns. For the medium-risk project (Table 2), if we fix the manager's wealth at $50 \%$ cash and $50 \%$ options, the range of hurdle rates is $-25.00 \%$ (when the ratio of alpha to wealth equals $0 \%$ ) to $+25.00 \%$ (when the magnitude of career concerns equals $0.6 \%$ ).

Paying the manager entirely in cash works well when career concerns are zero, but leads to an ever increasing under-investment problem as the ratio of alpha to wealth increases. The underinvestment problem is exacerbated when shares are substituted for cash. For example, in Table 2, if we fix the magnitude of career concerns at $0.4 \%$, the manager's hurdle rate rises from $6.45 \%$ (when his wealth consists of $100 \%$ cash) to $12.36 \%$ (when his wealth consists of $75 \%$ cash and $25 \%$ shares).

Options, with their convex payoffs, can be used to overcome the manager's reluctance to invest. For example, in Table 2, keeping the magnitude of career concerns fixed at $0.4 \%$, the manager lowers his hurdle rate to $+0.11 \%$ when his wealth consists of $75 \%$ cash, $15 \%$ shares and $10 \%$ options. With this mix of wealth, the manager's interests are nearly aligned with those of shareholders.

With too much option wealth, the manager over-invests. In Table 2, "too much" option wealth can be as little as 5 or $10 \%$ of wealth. For example, if we fix the magnitude of career concerns at $0.2 \%$, the manager sets his hurdle rate at $-6.98 \%$ when his wealth consists of $75 \%$ cash, $15 \%$ shares and $10 \%$ options. Tables $1-3$ show that over-investment is far more likely and far more severe than many researchers suggest (see, for example, Lambert et al., 1991; Guay, 1999; and Aggarwal and Samwick, 1999).

There are a variety of ways to achieve incentive alignment between managers and shareholders. Depending on investment risks and executive-specific risk and wealth parameters, stock options can be a small or large component of executive pay. Kole (1997) and Murphy (1999) find considerable 
variation in compensation awards across industries. Tables $1-3$ show that incentive alignment is not inconsistent with this result.

Two other features of Tables $1-3$ are worth noting. First, increasing the share of option wealth generally leads to increased risk-taking on the part of the manager. However, when options comprise a large portion of compensation, the reverse effect is possible. Second, fixing the manager's mix of wealth and increasing a project's risk leads to decreased risk-taking on the part of the manager, unless the magnitude of career concerns is small. An increase in project risk has two conflicting effects on an option's value to the manager: a positive effect from the convexity of the option's payoff (wealth effect), and a negative effect from the concavity of the manager's utility function (risk-aversion effect). In Tables $1-3$, the wealth effect dominates when the ratio of alpha to wealth is less than or equal to $0.2 \%$ and the risk-aversion effect dominates when this ratio is greater than $0.2 \%$.

Several studies (e.g., Guay, 1999; Rajgopal and Shevlin, 1999) find that options are used to encourage risk-taking, and more option pay is associated with greater risk taking. These studies implicitly assume the extra risk-taking is beneficial to shareholders. Our analysis indicates it is quite easy for firms to overshoot and encourage excessive risk-taking. Moreover, substituting options for shares in a manager's compensation award does not always increase a manager's incentives to take risks, and may have the reverse effect.

In summary, Tables $1-3$ show that managerial incentives to take risk are multi-dimensional. Simply using the value of option compensation or the ratio of option compensation to overall compensation as a proxy for the magnitude of a manager's incentive to increase stock prices or volatility is inaccurate. Studies that measure managerial risk-taking as a function of share holdings or options alone suffer from a mis-specification problem. Moreover, the standard practice of using managerial share holdings as a proxy for corporate agency costs in cross-sectional regressions may 
be problematic (see, for example, Morgan and Poulsen, 2001; and Carter and Lynch, 2001).

\subsection{Option strike prices and managerial investment}

We next consider the effect of option strike prices on managerial incentives to invest. Table 4 fixes the magnitude of career concerns at $0.2 \%$ and reports hurdle rates for the medium risk project. We consider a range of strike prices from $\$ 70$ to $\$ 150$, with $\$ 100$ being at-the-money. As in Tables 1 - 3, we follow Johnson and Tian (2000) and Hall and Murphy (2000) and compare schemes of equal cost from the perspective of risk-neutral shareholders.

Managerial incentives to invest are highly sensitive to option strike prices. Within Table 4, hurdle rates vary from $-15.11 \%$ to $+25.00 \%$. Fixing option wealth at only $10 \%$ (with shares at $15 \%$ and cash at $75 \%$ ), the range of hurdle rates is $-6.98 \%$ to $+8.05 \%$. Compared to options granted atthe-money, a 10\% change in the option strike price can move the manager's hurdle rate up or down more than 9 percentage points. These results conflict with Hall and Murphy (2000) who find little variation in the incentives provided by stock options over a wide range of strike prices. One reason our results differ is because we link managerial behavior to firm value, whereas Hall and Murphy (2000) do not.

We illustrate part of Table 4 in Figure 1. Here we look at managerial investment when the ratio of alpha to wealth is fixed at $0.2 \%$ and $50 \%$ of the manager's wealth is in cash. The figure displays hurdle rates for a range of option strike prices for different mixes of share and option wealth. Two features of the figure are worth noting. First, at-the-money options $(\mathrm{X}=\mathrm{I})$ induce the most risk taking, although premium options may do a better job of aligning executive and shareholder interests. Second, risk-taking behavior is not symmetric around $\mathrm{X}=\mathrm{I}$. When $\mathrm{X}>\mathrm{I}$, the manager's response to higher exercise prices is fairly muted; gradually, he increases his hurdle rate (i.e., accepts fewer risky 
projects). However, when $\mathrm{X}<\mathrm{I}$, the manager's investment behavior responds dramatically to changes in the option's exercise price.

The relation between managerial investment and option strike prices bears directly on the issue of re-pricing options. Our analysis indicates that if incentive alignment were the primary rationale for executive stock option awards, we would expect to see option re-pricing both when stock prices fall and when they rise. ${ }^{15}$ In fact, since a manager's investment behavior responds so dramatically to a rise in an option's intrinsic value, we would expect to see more frequent option re-pricing when stock prices rise (and options resemble shares). Quite the reverse, Brenner, Sundaram and Yermack (2000) find that more than $99 \%$ of all re-pricing events are associated with a reduction in the option strike price, following a decline in stock prices.

Our analysis also indicates that the distribution of a manager's wealth has a large impact on his incentives to invest. Thus, if incentive alignment were the primary rationale for stock option awards, we would expect to see companies monitor executive wealth and possibly place restrictions on share holdings, which tend to encourage risk-avoidance and counteract the desired effects of stock options. We have no evidence of either practice, though some firms mandate minimal shareholdings for executives (see Core and Larcker, 2001). In contrast, Ofek and Yermack (2000) find evidence that executives prefer to sell shares whenever possible.

\section{Risk-taking incentives and firm value}

15 In drawing a parallel between the results of table 5 and the re-pricing phenomenon, we are assuming that options are re-priced at constant cost. Hall and Murphy (2000b) call this a "Black-Scholes" re-pricing and cite General Dynamics as one of the first companies to adopt such a practice in 1991. Brenner, Sundaram, and Yermack (2000) find that from an ex-ante standpoint, re-pricing produces a small benefit to executives, generally less than $15 \%$ of the initial option award value. Callaghan, Saly, and Subramaniam (2000) obtain similar estimates of the benefit executives derive from option re-pricing events. 
In this section we examine risk-taking incentives and firm value. Table 5 reports firm value under the manager's investment strategy for various divisions of wealth and incentive compensation and for a range of career concerns. We present results for the medium-risk project only, and we compute firm value using equation (2). Equation (2) ignores the cost of the manager's compensation, but this is not a problem because we are comparing firm values derived from compensation schemes of equal cost.

Firm value is highly sensitive to the distribution of wealth and the magnitude of executive career concerns. If we fix the magnitude of career concerns at $0.4 \%$, firm value varies from $\$ 106.25$ (when wealth consists of $50 \%$ cash, $10 \%$ shares and $40 \%$ options) to $\$ 100.00$ (when wealth consists of $25 \%$ cash and any mix of shares and options). If we fix the manager's wealth at $50 \%$ cash and $50 \%$ shares, firm value varies from $\$ 105.61$ (when career concerns are nil) to $\$ 100.00$ (when the magnitude of career concerns is $0.6 \%$ ).

Contrary to the implications of risk-neutral option valuation models, firm value is not an increasing function of a manager's option wealth or the "delta" of his portfolio. For example, with the ratio of alpha to wealth fixed at $0.4 \%$, firm value is $\$ 104.72$ when the manager's wealth consists of $75 \%$ cash and $25 \%$ shares. Firm value rises to $\$ 106.25$ (when the manager's wealth consists of $75 \%$ cash, $15 \%$ shares and $10 \%$ options) but falls to $\$ 105.64$ (when the manager's wealth consists of $75 \%$ cash and $25 \%$ options). Stronger managerial incentives to invest can benefit or harm a firm, depending on the firm's investment opportunities and executive specific risk and wealth parameters. ${ }^{16}$

We illustrate sections of Table 5 in Figures 2 - 4, where we fix one component of wealth and

\footnotetext{
16 Managerial risk-aversion is not driving this result. If we set the magnitude of career concerns equal to zero and the manager's coefficient of relative risk aversion, b, equal to zero (i.e., if the manager is risk-neutral), this result still holds. Firm value is not strictly increasing in managerial option wealth as long as firm value is endogenous. In contrast, risk-neutral valuation models treat firm value as exogenous and independent of managerial decisions.
} 
show firm value as a function of career concerns and the mix of other wealth. In Figure 2, cash represents $50 \%$ of managerial wealth. Here we see that when career concerns are low, substituting shares for options results in an increase in firm value. In Figure 3, shares represent $50 \%$ of managerial wealth. Here we see that once options constitute about $10 \%$ of wealth, increasing option wealth by substituting options for cash results in a decrease in firm value. In Figure 4, options represent $25 \%$ of managerial wealth. Here we see that when career concerns are high, substituting cash for shares results in an increase in firm value. In summary, Figures $2-4$ confirm that firm value is highly sensitive to the distribution of wealth and the magnitude of executive career concerns.

\subsection{Pay-for-performance and firm value}

It is possible to assess the extent to which an executive participates in wealth creation by estimating pay-for-performance (PFP) measures. Jensen and Murphy (1990) examine PFP and estimate that the average executive experiences a wealth increase of $\$ 3.25$ for every $\$ 1,000$ increase in his firm's value. Such a low pay-for-performance sensitivity challenges the principal-agent paradigm, which predicts, in the case of risk-neutral managers, a one for one relation between executive and shareholder gains. Low pay sensitivities, however, may provide adequate incentives if managers are risk-averse (Haubrich, 1994), or if firms are highly levered (John and John, 1993). Consistent with the principal-agent paradigm, pay-performance measures decrease, and salaries increase, as firm and CEO incomes become more volatile (Garen, 1994). Stock options, used only modestly in the time period that Jensen and Murphy study, bolster pay-for-performance measures (Hall and Liebman, 1998) and provide powerful incentive effects (Guay, 1999).

Following Jensen and Murphy (1990), we define pay-for-performance sensitivity (PFP) as the change in managerial compensation associated with a $\$ 1,000$ change in firm value, for all possible 
liquidation values of the firm. We describe the computation method for this measure in Appendix B.

We also compute a pay-for-performance measure based on the Black-Scholes option pricing model, as described in Guay (1999). ${ }^{17}$ The former measure allows for variation in executive career concerns; the latter ignores career concerns.

Table 6 reports pay for performance measures for various divisions of wealth and incentive compensation and for a range of career concerns. Column one uses the PFP measure described by Guay (1999); the remaining columns use the PFP measure outlined in Appendix B. We see that fixing the manager's career concerns, there is a positive relation between option wealth and PFP. If we fix the manager's mix of wealth, PFP declines as career concerns increase.

Figures 5 and 6 illustrate the relation between firm value (again, without netting out the cost of the manager's compensation) and pay-for-performance. Both figures are based on the PFP measure outlined in Appendix B. In Figure 5, we fix cash wealth at 75\%; in Figure 6 we fix cash wealth at $50 \%$. The figures show that fixing the manager's career concerns, there is no simple monotonic relation between PFP and firm value. In a simple regression of the firm value observations from Table 5 on the PFP measures in Table 6 , the coefficient on the PFP measure is not statistically significant. ${ }^{18}$

Our results have implications for studies that examine the relation between executive compensation and corporate investment decisions, such as Aggarwal and Samwick (1999), and Datta, Iskandar-Datta and Raman (2000). Using pay-for-performance measures to describe the degree of alignment between managers and shareholders, while ignoring managerial differences in wealth and

\footnotetext{
17 We assume stock prices follow a lognormal process with expected return and volatility parameters equal to $6.25 \%$ and $28.9 \%$ respectively (same as the medium-risk project). We assume options are granted at-the-money and expire in two years, with the risk-free rate equal to $0 \%$.

18 We don't mean to suggest that the rows of Tables 5 and 6 represent a reasonable division of managerial wealth at a cross-section of firms.
} 
risk preferences may introduce measurement error problems that generate misleading inferences.

Our results also have implications for studies of ownership structure and firm performance, such as Demsetz and Villalonga (2000), Himmelberg, Hubbard and Palia (1999) and Ljungqvist and Habib (2000). Focusing on one dimension of compensation such as managerial share holdings, while ignoring options and other wealth as well as cross-sectional variation in managerial risk preferences may lead to spurious inferences about the relation between ownership and firm performance.

\subsection{Robustness}

The results we present in Tables $1-6$ and Figures $1-6$ are quite robust to changes in the parameters of our model, including project cash flows, alpha-to-wealth ratios, risk-aversion coefficients and risk-free rates. The conclusions of our paper are valid with any managerial utility function that exhibits decreasing absolute risk aversion. Our results do not depend on our assumption that the manager's human capital is linear in firm value. Moreover, our results do not depend on our assumption that managerial career concerns are responsible for the agency problem between managers and shareholders. Similar results obtain as long as the manager's indirect utility function is concave in firm value.

\section{Conclusions}

This paper examines the effect of stock options on managerial incentives to invest. We develop a model in which firm value is endogenous: a manager affects firm value through his investment decisions, which depend on the manager's risk and wealth parameters. We then solve the model numerically for a variety of parameterizations that are consistent with the marketplace.

We find that managerial incentives to invest are multi-dimensional and highly sensitive to 
option strike prices, the manager's wealth, degree of diversification, risk aversion, and career concerns. Under and over-investment problems can be large and economically significant, with hurdle rates ranging from more than 20 percentage points below to more than 35 percentage points above shareholders' required rate of return. The likelihood and severity of over-investment problems is greater than many researchers suggest.

There is no simple monotonic relation between pay-for-performance and firm value. Firm value is not a strictly increasing function of a manager's incentive compensation. Stronger managerial incentives to invest can benefit or harm a firm, depending on the firm's investment opportunities and executive specific risk and wealth parameters. Moreover, increasing the amount of incentive pay does not necessarily increase the incentive to take risks, and may even decrease it.

Our results should send a cautionary signal to researchers who study managerial behavior. It is not sufficient to rely on one-dimensional risk-neutral valuation metrics, such as pay-for-performance, to describe the degree of alignment between managers and shareholders. Ignoring managerial differences in wealth and risk preferences may introduce measurement errors that generate misleading inferences. Moreover, the standard practice of using managerial share holdings as a proxy for corporate agency costs may be problematic. 


\section{References}

Aggarwal, R.K., Samwick, A.A., 1999. Empire-builders and shirkers: investment, firm performance, and managerial incentives. Working paper. Dartmouth College, Hanover, NH.

Allen, F., 2001. Presidential address: do financial institutions matter? Journal of Finance 56, 11651176.

Brenner, M., Sundaram, R., Yermack, D., 2000. Altering the terms of executive stock options. Journal of Financial Economics 57, 103-128.

Callaghan, S.R., Saly, P. J. and C. Subramaniam, 2000. The timing of option repricing. Working paper. Texas Christian University, Fort Worth, TX.

Carter, M.E., Lynch, L.J., 2000. An examination of executive stock option repricing. Journal of Financial Economics, forthcoming.

Conyon, M.J., Murphy, K., 2000. The prince and the pauper? CEO pay in the United States and United Kingdom. The Economic Journal 100, F640-71.

Core, J.E., Larcker, D.F., 2001. Performance consequences of mandatory increases in CEO stock ownership. Working paper. University of Pennsylvania, Philadelphia, PA.

Datta, S., Iskandar-Datta, M., Raman, K., 2000. Executive compensation and corporate acquisition decisions. Journal of Finance, forthcoming.

DeFusco, R., Johnson, R., Zorn, T., 1990. The effect of executive stock option plans on stockholders and bondholders. Journal of Finance 45, 617-627.

Demsetz, H., Villalonga, B., 2001. Ownership structure and corporate performance. Working paper. University of California, Los Angeles, CA.

Dimson, E., Marsh, P., 2001. U.K. financial market returns, 1955 - 2000. Journal of Business 74, $1-31$.

Fee, C.E., Hadlock, C.J., 2001. Raids, rewards, and reputations in the market for CEO talent. Working paper. Michigan State University, East Lansing, MI.

Friend, I., Blume, M., 1975. The demand for risky assets. American Economic Review (December), 901-922.

Garen, J., 1994. Executive compensation and principal-agent theory. Journal of Political Economy $102,1175-1199$. 
Gavish, B. and A. Kalay, 1983. On the Asset Substitution Problem. Journal of Financial and Quantitative Analysis 18, 21-30.

Gibbons, R., Murphy, K., 1992. Optimal incentive contracts in the presence of career concerns. Journal of Political Economy 100, 468-505.

Graham, J., 1999. Herding among investment newsletters: theory and evidence. Journal of Finance 54, 237-268.

Guay, W., 1999. The sensitivity of CEO wealth to equity risk: an analysis of the magnitude and determinants. Journal of Financial Economics 53, 43-71.

Hall, B., Leibman, J., 1998. Are CEOs really paid like bureaucrats? Quarterly Journal of Economics $113,653-691$.

Hall, B., Murphy, K., 2000. Optimal exercise prices for executive stock options. American Economic Review 90, 209-214.

Hall, B., Murphy, K., 2000b. Stock options for undiversified executives. Working paper. Harvard Business School, Cambridge, MA.

Haubrich, J., 1994. Risk aversion, performance pay, and the principal-agent problem. Journal of Political Economy 102, 258-276.

Hemmer, T., Matsunaga, S., Shevlin, T., 1996. The influence of risk diversification on the early exercise of employee stock options by executive officers. Journal of Accounting and Economics 21, 45-68.

Himmelberg, C.P., Hubbard, R.G., Palia, D., 1999. Understanding the determinants of managerial ownership and the link between ownership and performance. Journal of Financial Economics 53, 353-384.

Holmstrom, B., Ricart i Costa, J., 1986. Managerial incentives and capital management. Quarterly Journal of Economics 101, 835-860.

Jagannathan, R., Wang, Z., 1996. The conditional CAPM and the cross-section of expected returns. Journal of Finance 51, 3-53.

Jensen, M., Murphy, K., 1990. Performance pay and top management incentives. Journal of Political Economy 98, 225-264.

John, K., John, T., 1993. Top management compensation and capital structure. Journal of Finance 48, 949-974. 
Johnson, S.A., Tian, Y.S., 2000. The value and incentive effects of non-traditional executive stock option plans. Journal of Financial Economics 57, 3-34.

Kaplan, R., 1984. The evolution of management accounting. The Accounting Review 59, 390-418.

Kole, S., 1997. The complexity of compensation contracts. Journal of Financial Economics 43, 79104.

Lambert, R., 1986, Executive effort and the selection of risky projects. Rand Journal of Economics $17,77-88$.

Lambert, R., Larcker, D., Verrechia, R., 1991. Portfolio considerations in valuing executive compensation. Journal of Accounting Research 29, 129-149.

Litzenberger, R., Ronn, E., 1986. A utility-based model of common stock price movements. Journal of Finance (March), 67-92.

Ljungqvist, A.P., Habib, M.A., 2000. Firm value and managerial incentives. Working paper. New York University, New York, NY.

Milgrom, P., Roberts, J., 1992. Economics, Organization and Management. Englewood Cliffs, NJ, Prentice Hall.

Morgan, A.G., Poulsen, A.B., 2001. Linking pay to performance - compensation proposals in the S\&P 500. Journal of Financial Economics, forthcoming.

Murphy, K.J., 1999. Executive compensation. In: Ashenfelter, O., Card, D. (Eds.), Handbook of Labor Economics, Vol. 3. North-Holland, Amsterdam.

Nohel, T., Todd, S., 2001. Optimal compensation for risk-averse executives with career concerns. Working paper. Loyola University Chicago, Chicago, IL.

Ofek, E., Yermack, D., 2000. Taking stock: equity-based compensation and the evolution of managerial ownership. Journal of Finance 55, 1367-1384.

Perry, T., Zenner, M., 2000. Pay for performance? Government regulation and the structure of compensation contracts. Journal of Financial Economics, forthcoming.

Rajgopal, S., Shevlin, T., 1999. Stock option compensation and risk taking: the case of oil and gas producers. Working paper. University of Washington, Seattle, WA.

Ross, S., 1977. The determination of financial structure: the incentive-signaling approach. Bell Journal of Economics 8, 23-40. 
Yermack, D., 1997. Good timing: CEO stock option awards and company news announcements. Journal of Finance 52, 449-476. 


\section{Appendix A: Valuing a call option based on the investment strategy, $\left[\widetilde{V}_{H}\right]$}

Here we derive a formula for calculating the value of a call option, assuming the manager

pursues the investment strategy, $\left[\hat{V}_{H}\right]$. If the manager takes the riskless project, the final stock price (at $t=2$ ) is known with certainty. A call option on the entire firm with exercise price $X$, expiring at $\mathrm{t}=2$, is worth $\operatorname{Max}(0, I-X)$. When the manager takes the risky project, the value of a call option on the firm (ignoring compensation costs) is:

$$
\text { CallValue }=\frac{1}{V_{H}-V_{L}} \int_{V_{L}}^{V_{H}} \operatorname{Max}(0, V-X) d V
$$

Thus, if the manager follows investment policy, $\left[\hat{V}_{H}\right]$, the call value at time 0 is:

$$
\begin{aligned}
& C_{0}=\frac{1}{V_{H 2}-V_{H 1}} \int_{V_{H 1}}^{\hat{V}_{H}} \operatorname{Max}(0, I-X) d V_{H}+ \\
& \frac{1}{V_{H 2}-V_{H 1}} \int_{\hat{V}_{H}}^{V_{H 2}}\left[\frac{1}{V_{H}-V_{L}} \int_{V_{L}}^{V_{H}} \operatorname{Max}(0, V-X) d V\right] d V_{H}
\end{aligned}
$$

The first integral represents the call's payoff under the riskless project, while the second integral represents the call's expected payoff under the risky project. To simplify expression (A2), we separately consider the cases $X<\hat{V}_{H}$ and $X>\hat{V}_{H}$. If $X<\hat{V}_{H}$, then:

$$
C_{0}=\frac{\hat{V}_{H}-V_{H 1}}{V_{H 2}-V_{H 1}} \operatorname{Max}(0, I-X)+\frac{1}{V_{H 2}-V_{H 1}} \int_{\hat{V}_{H}}^{V_{H 2}}\left[\frac{1}{V_{H}-V_{L}} \int_{X}^{V_{H}}(V-X) d V\right] d V_{H}
$$


Alternatively, if $X>\hat{V}_{H}$ then:

$$
C_{0}=\frac{\hat{V}_{H}-V_{H 1}}{V_{H 2}-V_{H 1}} \operatorname{Max}(0, I-X)+\frac{1}{V_{H 2}-V_{H 1}} \int_{X}^{V_{H 2}}\left[\frac{1}{V_{H}-V_{L}} \int_{X}^{V_{H}}(V-X) d V\right] d V_{H}
$$

These can be integrated to give the following valuation formulae for the call option at $\mathrm{t}=0$. If $X<\hat{V}_{H}$ :

$$
\begin{aligned}
& C_{0}=\frac{\hat{V}_{H}-V_{H 1}}{V_{H 2}-V_{H 1}} \operatorname{Max}(0, I-X)+\frac{1}{2\left(V_{H 2}-V_{H 1}\right)} * \\
& {\left[\frac{\left(V_{H 2}-V_{L}\right)^{2}}{2}-\frac{\left(\hat{V}_{H}-V_{L}\right)^{2}}{2}-2\left(X-V_{L}\right)\left(V_{H 2}-\hat{V}_{H}\right)+\left(X-V_{L}\right)^{2} \ln \left(\frac{V_{H 2}-V_{L}}{\hat{V}_{H}-V_{L}}\right)\right]}
\end{aligned}
$$

If $X>\hat{V}_{H}$ :

$$
\begin{aligned}
& C_{0}=\frac{\hat{V}_{H}-V_{H 1}}{V_{H 2}-V_{H 1}} \operatorname{Max}(0, I-X)+\frac{1}{2\left(V_{H 2}-V_{H 1}\right)} * \\
& {\left[\frac{\left(V_{H 2}-V_{L}\right)^{2}}{2}-\frac{\left(X-V_{L}\right)^{2}}{2}-2\left(X-V_{L}\right)\left(V_{H 2}-X\right)+\left(X-V_{L}\right)^{2} \ln \left(\frac{V_{H 2}-V_{L}}{X-V_{L}}\right)\right]}
\end{aligned}
$$




\section{Appendix B: Pay-for-performance}

Following Jensen and Murphy (1990), we define pay-for-performance sensitivity (PFP) as the change in compensation value associated with a $\$ 1,000$ change in firm value for all possible liquidation values of the firm, given a fixed compensation package. The value of cash compensation is uncorrelated with changes in firm value, while the value of share and option compensation is positively correlated with changes in firm value. Thus, PFP is zero for cash compensation and positive for shareand option-based compensation. In our model, the firm's value is $\mathrm{V}_{0+}$ once the manager is hired. As firm value moves from $\mathrm{V}_{0+}$ to $\mathrm{V}$ (its liquidation value), the value of the manager's incentive compensation changes by:

$$
\left(m^{*} \operatorname{Max}\left[V-X^{*}, 0\right]+n^{*} V+K^{*}\right)-\left(m * C_{0+}+n^{*} V_{0+}+K^{*}\right)
$$

Rearranging terms, the change in the value of the manager's compensation, as a function of the change in firm value from $t=0+$ to $t=2$, i.e., as firm value changes from $V_{0+}$ to $V$, is:

$$
\Delta \text { Pay }=\left\{\begin{array}{cc}
m^{*}\left(V_{0+}-X^{*}-C_{0+}\right)+\left(n^{*}+m^{*}\right) \Delta \text { Value, } & \text { when } V>X^{*} \\
-m^{*} C_{0+}+n^{*} \Delta \text { Value, } & \text { when } V \leq X^{*}
\end{array}\right\}
$$

We define PFP as the coefficient of $\Delta$ Value in (B2), consistent with Jensen and Murphy (1990a,b). It is straightforward to show that PFP is defined as:

$$
\mathrm{PFP}=\mathrm{n}+\left[\mathrm{m} * \operatorname{Prob}(\text { risky }) * \operatorname{Prob}\left(\mathrm{V}>\mathrm{X}^{*} \mid \text { risky }\right)\right]
$$

Here, Prob(risky) is the probability that the manager pursues the risky project, and $\operatorname{Prob}\left(\mathrm{V}>\mathrm{X}^{*} \mid\right.$ risky) is the probability that the risky project payoff exceeds the option strike price, given the risky project is selected. 
Table 1

Managerial investment in the low risk project

\% Share of managerial wealth as:

\begin{tabular}{|rrrrrrrr|}
\hline Cash & Shares & Options & $\alpha$ /Wealth & $0 \%$ & $0.2 \%$ & $0.4 \%$ & $0.6 \%$ \\
\hline 25 & 75 & 0 & 2.86 & 3.92 & 5.16 & 6.62 \\
25 & 50 & 25 & -6.79 & -5.00 & -3.02 & -0.68 \\
25 & 25 & 50 & -9.27 & -7.05 & -4.28 & -0.46 \\
25 & 0 & 75 & -12.50 & -8.54 & -2.61 & 11.38 \\
\hline 50 & 50 & 0 & 1.75 & 2.65 & 3.68 & 4.88 \\
50 & 40 & 10 & -6.06 & -4.29 & -2.59 & -0.83 \\
50 & 30 & 20 & -8.19 & -6.45 & -4.72 & -2.85 \\
50 & 20 & 30 & -9.55 & -7.75 & -5.95 & -3.93 \\
50 & 10 & 40 & -10.73 & -8.77 & -6.83 & -4.58 \\
50 & 0 & 50 & -12.50 & -9.71 & -7.55 & -4.93 \\
\hline 75 & 25 & 0 & 0.81 & 1.58 & 2.45 & 3.45 \\
75 & 20 & 5 & -6.71 & -4.39 & -2.59 & -0.94 \\
75 & 15 & 10 & -8.71 & -6.47 & -4.66 & -2.96 \\
75 & 10 & 15 & -9.93 & -7.70 & -5.91 & -4.20 \\
75 & 5 & 20 & -10.94 & -8.59 & -6.81 & -5.09 \\
75 & 0 & 25 & -12.50 & -9.32 & -7.52 & -5.78 \\
\hline 100 & 0 & 0 & 0.00 & 0.66 & 1.41 & 2.26 \\
\hline
\end{tabular}

The risky project cash flows are uniformly distributed on the interval $\left(75, \mathrm{~V}_{\mathrm{H}}\right)$ with $\mathrm{V}_{\mathrm{H}}$ uniformly distributed on the interval $(100,150)$. The manager has a coefficient of relative risk aversion equal to 3.0. Alpha measures the magnitude of the manager's career concerns. Under shareholders' preferred investment strategy, the manager sets the hurdle rate at $0.00 \%$. 


\section{Table 2}

Managerial investment in the medium risk project

\% Share of managerial wealth as:

\begin{tabular}{|c|c|c|c|c|c|c|c|}
\hline Cash & Shares & Options & $\alpha /$ Wealth & $0 \%$ & $0.2 \%$ & $0.4 \%$ & $0.6 \%$ \\
\hline 25 & 75 & 0 & & 14.63 & 23.09 & 25.00 & 25.00 \\
\hline 25 & 50 & 25 & & -4.81 & 6.31 & 25.00 & 25.00 \\
\hline 25 & 25 & 50 & & -13.40 & 0.41 & 25.00 & 25.00 \\
\hline 25 & 0 & 75 & & -25.00 & -5.22 & 25.00 & 25.00 \\
\hline 50 & 50 & 0 & & 8.00 & 13.46 & 21.33 & 25.00 \\
\hline 50 & 40 & 10 & & -5.79 & 1.49 & 10.91 & 25.00 \\
\hline 50 & 30 & 20 & & -11.63 & -4.21 & 5.79 & 22.15 \\
\hline 50 & 20 & 30 & & -15.81 & -8.24 & 2.37 & 21.25 \\
\hline 50 & 10 & 40 & & -19.59 & -11.71 & -0.33 & 22.18 \\
\hline 50 & 0 & 50 & & -25.00 & -15.11 & -2.78 & 25.00 \\
\hline 75 & 25 & 0 & & 3.39 & 7.21 & 12.36 & 19.69 \\
\hline 75 & 20 & 5 & & -9.13 & -2.17 & 4.64 & 13.13 \\
\hline 75 & 15 & 10 & & -14.19 & -6.98 & 0.11 & 9.00 \\
\hline 75 & 10 & 15 & & -17.60 & -10.27 & -3.10 & 6.03 \\
\hline 75 & 5 & 20 & & -20.51 & -12.84 & -5.64 & 3.71 \\
\hline 75 & 0 & 25 & & -25.00 & -15.05 & -7.79 & 1.79 \\
\hline 100 & 0 & 0 & & 0 & 2.82 & 6.45 & 11.32 \\
\hline
\end{tabular}

The risky project cash flows are uniformly distributed on the interval $\left(50, \mathrm{~V}_{\mathrm{H}}\right)$ with $\mathrm{V}_{\mathrm{H}}$ uniformly distributed on the interval $(100,200)$. The manager has a coefficient of relative risk aversion equal to 3.0. Alpha measures the magnitude of the manager's career concerns. Under shareholders' preferred investment strategy, the manager sets the hurdle rate at $0.00 \%$. 


\section{Table 3}

Managerial investment in the high risk project

\% Share of managerial wealth as:

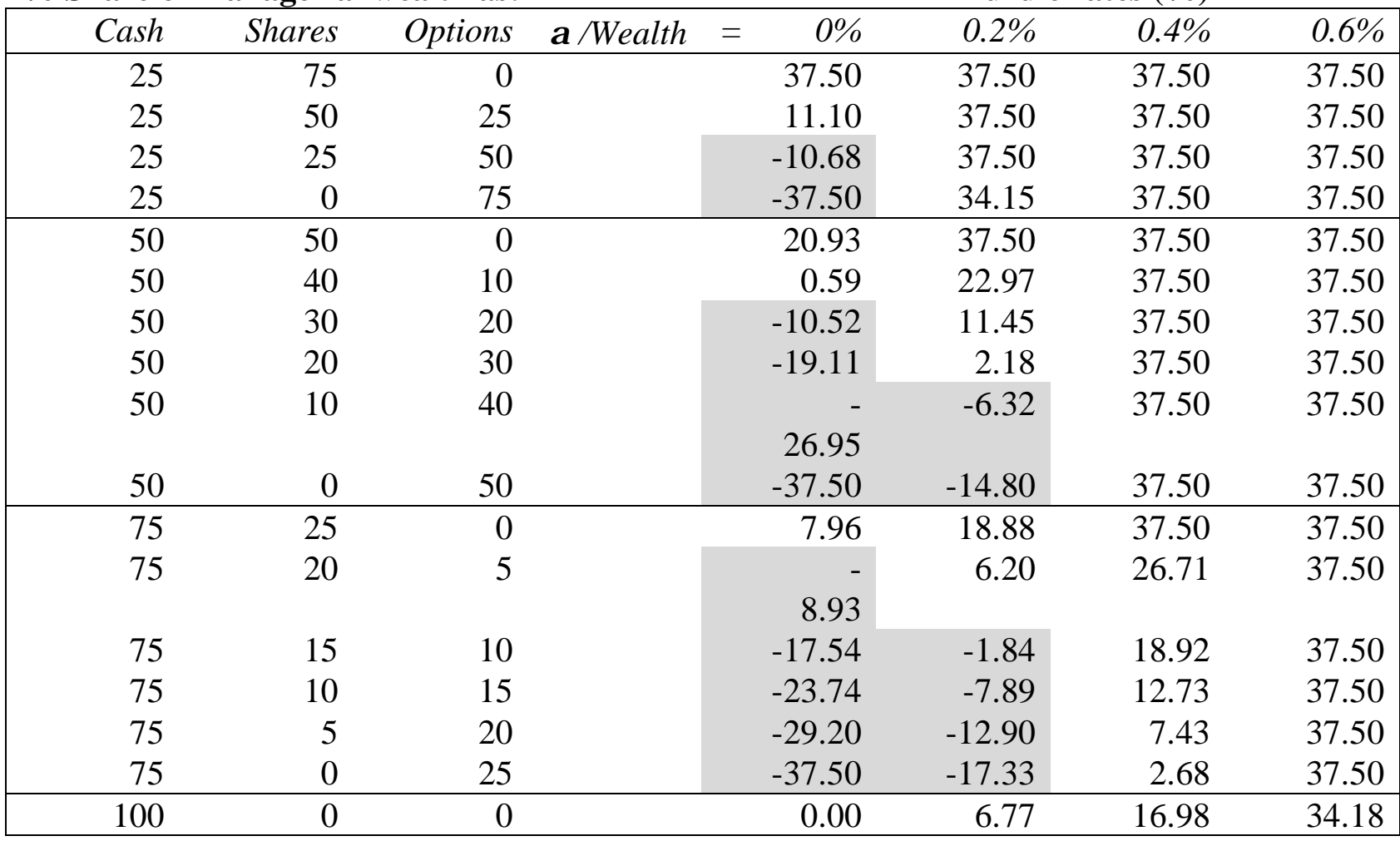

The risky project cash flows are uniformly distributed on the interval $\left(25, \mathrm{~V}_{\mathrm{H}}\right)$ with $\mathrm{V}_{\mathrm{H}}$ uniformly distributed on the interval $(100,250)$. The manager has a coefficient of relative risk aversion equal to 3.0. Alpha measures the magnitude of the manager's career concerns. Under shareholders' preferred investment strategy, the manager sets the hurdle rate at $0.00 \%$. 


\section{Table 4}

Managerial investment in the medium risk project for various option strike prices

$\%$ Share of

managerial wealth as:
Hurdle rates $(\%)$

Option Strike Price

\begin{tabular}{|rrr|rrrrrr|}
\hline Cash & Shares & Options & 70 & 90 & 100 & 110 & 130 & 150 \\
\hline 25 & 75 & 0 & 23.09 & 23.09 & 23.09 & 23.09 & 23.09 & 23.09 \\
25 & 50 & 25 & 25.00 & 25.00 & 6.31 & 8.58 & 12.36 & 15.63 \\
25 & 25 & 50 & 25.00 & 25.00 & 0.41 & 3.84 & 9.42 & 13.90 \\
25 & 0 & 75 & 25.00 & 25.00 & -5.22 & -1.07 & 5.66 & 10.94 \\
\hline 50 & 50 & 0 & 13.46 & 13.46 & 13.46 & 13.46 & 13.46 & 13.46 \\
50 & 40 & 10 & 15.54 & 11.09 & 1.49 & 3.00 & 5.80 & 8.60 \\
50 & 30 & 20 & 18.40 & 11.09 & -4.21 & -1.73 & 2.71 & 6.84 \\
50 & 20 & 30 & 22.29 & 12.76 & -8.24 & -5.12 & 0.42 & 5.43 \\
50 & 10 & 40 & 25.00 & 16.14 & -11.71 & -8.11 & -1.68 & 4.07 \\
50 & 0 & 50 & 25.00 & 21.81 & -15.11 & -11.12 & -3.88 & 2.66 \\
\hline 75 & 25 & 0 & 7.21 & 7.21 & 7.21 & 7.21 & 7.21 & 7.21 \\
75 & 20 & 5 & 7.55 & 4.43 & -2.17 & -0.84 & 1.84 & 4.79 \\
75 & 15 & 10 & 8.05 & 2.90 & -6.98 & -4.79 & -0.57 & 3.70 \\
75 & 10 & 15 & 8.69 & 2.06 & -10.27 & -7.48 & -2.21 & 2.93 \\
75 & 5 & 20 & 9.47 & 1.70 & -12.84 & -9.61 & -3.54 & 2.29 \\
75 & 0 & 25 & 10.41 & 1.70 & -15.05 & -11.46 & -4.71 & 1.73 \\
\hline 100 & 0 & 0 & 2.82 & 2.82 & 2.82 & 2.82 & 2.82 & 2.82 \\
\hline
\end{tabular}

The risky project cash flows are uniformly distributed on the interval $\left(50, \mathrm{~V}_{\mathrm{H}}\right)$ with $\mathrm{V}_{\mathrm{H}}$ uniformly distributed on the interval $(100,200)$. The manager has a coefficient of relative risk aversion equal to 3.0. The ratio of alpha, the magnitude of the manager's career concerns, to wealth is fixed at $0.2 \%$. Under shareholders' preferred investment strategy, the manager sets the hurdle rate at $0.00 \%$. 


\section{Table 5}

Firm value, given the manager's investment strategy

\% Share of managerial wealth as:

\begin{tabular}{|c|c|c|c|c|c|c|c|}
\hline Cash & Shares & Options & $\alpha /$ Wealth & $0 \%$ & $0.2 \%$ & $0.4 \%$ & $0.6 \%$ \\
\hline 25 & 75 & 0 & & 104.11 & 100.92 & 100.00 & 100.00 \\
\hline 25 & 50 & 25 & & 106.02 & 105.85 & 100.00 & 100.00 \\
\hline 25 & 25 & 50 & & 104.45 & 106.25 & 100.00 & 100.00 \\
\hline 25 & 0 & 75 & & 100.00 & 105.98 & 100.00 & 100.00 \\
\hline 50 & 50 & 0 & & 105.61 & 104.44 & 101.70 & 100.00 \\
\hline 50 & 40 & 10 & & 105.92 & 106.22 & 105.06 & 100.00 \\
\hline 50 & 30 & 20 & & 104.90 & 106.07 & 105.92 & 101.34 \\
\hline 50 & 20 & 30 & & 103.75 & 105.57 & 106.19 & 101.73 \\
\hline 50 & 10 & 40 & & 102.41 & 104.88 & 106.25 & 101.33 \\
\hline 50 & 0 & 50 & & 100.00 & 103.97 & 106.17 & 100.00 \\
\hline 75 & 25 & 0 & & 106.14 & 105.73 & 104.72 & 102.37 \\
\hline 75 & 20 & 5 & & 105.42 & 106.20 & 106.03 & 104.53 \\
\hline 75 & 15 & 10 & & 104.24 & 105.76 & 106.25 & 105.44 \\
\hline 75 & 10 & 15 & & 103.15 & 105.20 & 106.15 & 105.89 \\
\hline 75 & 5 & 20 & & 102.04 & 104.60 & 105.93 & 106.11 \\
\hline 75 & 0 & 25 & & 100.00 & 103.99 & 105.64 & 106.22 \\
\hline 100 & 0 & 0 & & 106.25 & 106.17 & 105.83 & 104.97 \\
\hline
\end{tabular}

The risky project cash flows are uniformly distributed on the interval $\left(50, \mathrm{~V}_{\mathrm{H}}\right)$ with $\mathrm{V}_{\mathrm{H}}$ uniformly distributed on the interval $(100,200)$. The manager has a coefficient of relative risk aversion equal to 3.0. Alpha measures the magnitude of the manager's career concerns. Firm value is based on equation (2) in the text. At time 0 , firm value is $\$ 100.00$ 


\section{Table 6}

PFP, under manager's investment strategy

\% Share of managerial wealth as:

PFP

\begin{tabular}{|c|c|c|c|c|c|c|c|c|}
\hline Cash & Shares & Options & $\alpha /$ Wealth & $=0 \% * *$ & $0 \%$ & $0.2 \%$ & $0.4 \%$ & $0.6 \%$ \\
\hline 25 & 75 & 0 & & $\$ 7.06$ & $\$ 7.06$ & $\$ 7.06$ & $\$ 7.06$ & $\$ 7.06$ \\
\hline 25 & 50 & 25 & & 17.54 & 12.40 & 9.82 & 4.71 & 4.71 \\
\hline 25 & 25 & 50 & & 28.02 & 21.09 & 15.42 & 2.35 & 2.35 \\
\hline 25 & 0 & 75 & & 38.50 & 33.13 & 23.33 & 0 & 0 \\
\hline 50 & 50 & 0 & & 4.71 & 4.71 & 4.71 & 4.71 & 4.71 \\
\hline 50 & 40 & 10 & & 8.90 & 6.92 & 6.28 & 5.34 & 3.76 \\
\hline 50 & 30 & 20 & & 13.09 & 10.06 & 8.87 & 7.02 & 3.49 \\
\hline 50 & 20 & 30 & & 17.28 & 13.61 & 11.96 & 9.17 & 3.19 \\
\hline 50 & 10 & 40 & & 21.47 & 17.51 & 15.44 & 11.66 & 2.26 \\
\hline 50 & 0 & 50 & & 25.67 & 22.08 & 19.31 & 14.50 & 0 \\
\hline 75 & 25 & 0 & & 2.35 & 2.35 & 2.35 & 2.35 & 2.35 \\
\hline 75 & 20 & 5 & & 4.45 & 3.60 & 3.31 & 2.99 & 2.55 \\
\hline 75 & 15 & 10 & & 6.55 & 5.21 & 4.67 & 4.05 & 3.18 \\
\hline 75 & 10 & 15 & & 8.64 & 6.98 & 6.22 & 5.33 & 4.05 \\
\hline 75 & 5 & 20 & & 10.74 & 8.86 & 7.89 & 6.76 & 5.07 \\
\hline 75 & 0 & 25 & & 12.83 & 11.04 & 9.65 & 8.31 & 6.21 \\
\hline 100 & 0 & 0 & & 0 & 0 & 0 & 0 & 0 \\
\hline
\end{tabular}

The risky project cash flows are uniformly distributed on the interval $\left(50, \mathrm{~V}_{\mathrm{H}}\right)$ with $\mathrm{V}_{\mathrm{H}}$ uniformly distributed on the interval $(100,200)$. The manager has a coefficient of relative risk aversion equal to 3.0. Alpha measures the magnitude of the manager's career concerns. PFP measures the pay-forperformance sensitivity, i.e., the change in the value of the manager's compensation per $\$ 1,000$ change in shareholder wealth. See Appendix B for a description of PFP. **These pay-for-performance measures are computed from the Black-Scholes option pricing model, as described in Guay (1999). 
Figure 1

Managerial investment as a function of mix of wealth and option strike prices $\alpha /$ Wealth $=0.2 \% ;$ Cash $=50 \% ;$ Shares $=(50$ - Options $) \%$

Hurdle rate $(\%)$

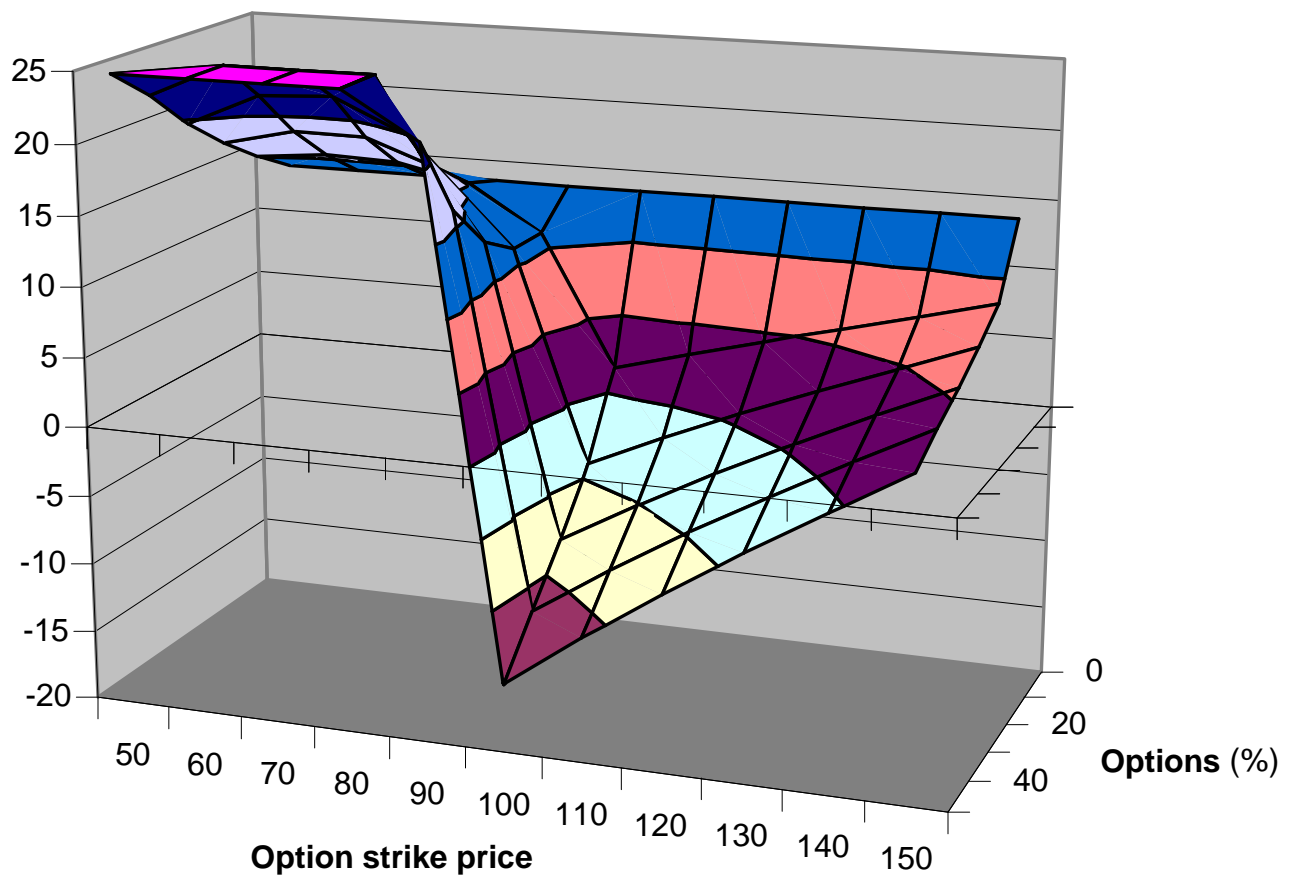


Figure 2

Firm Value as a function of career concerns and mix of wealth Cash $=50 \%$; Options $=(50-$ Shares $) \%$

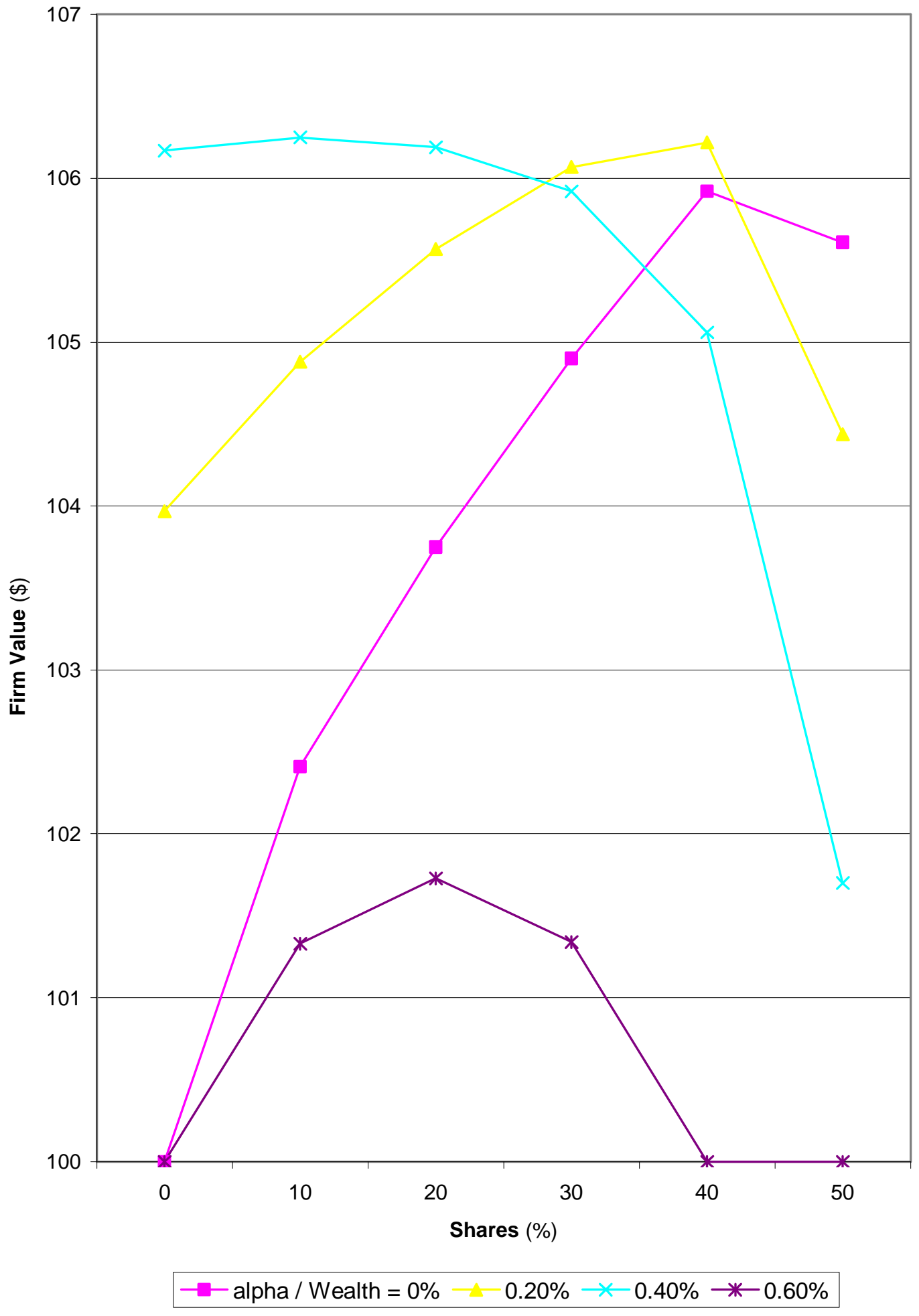


Figure 3

Firm Value as a function of career concerns and mix of wealth Shares $=50 \%$, Cash $=(50$ - Options $) \%$

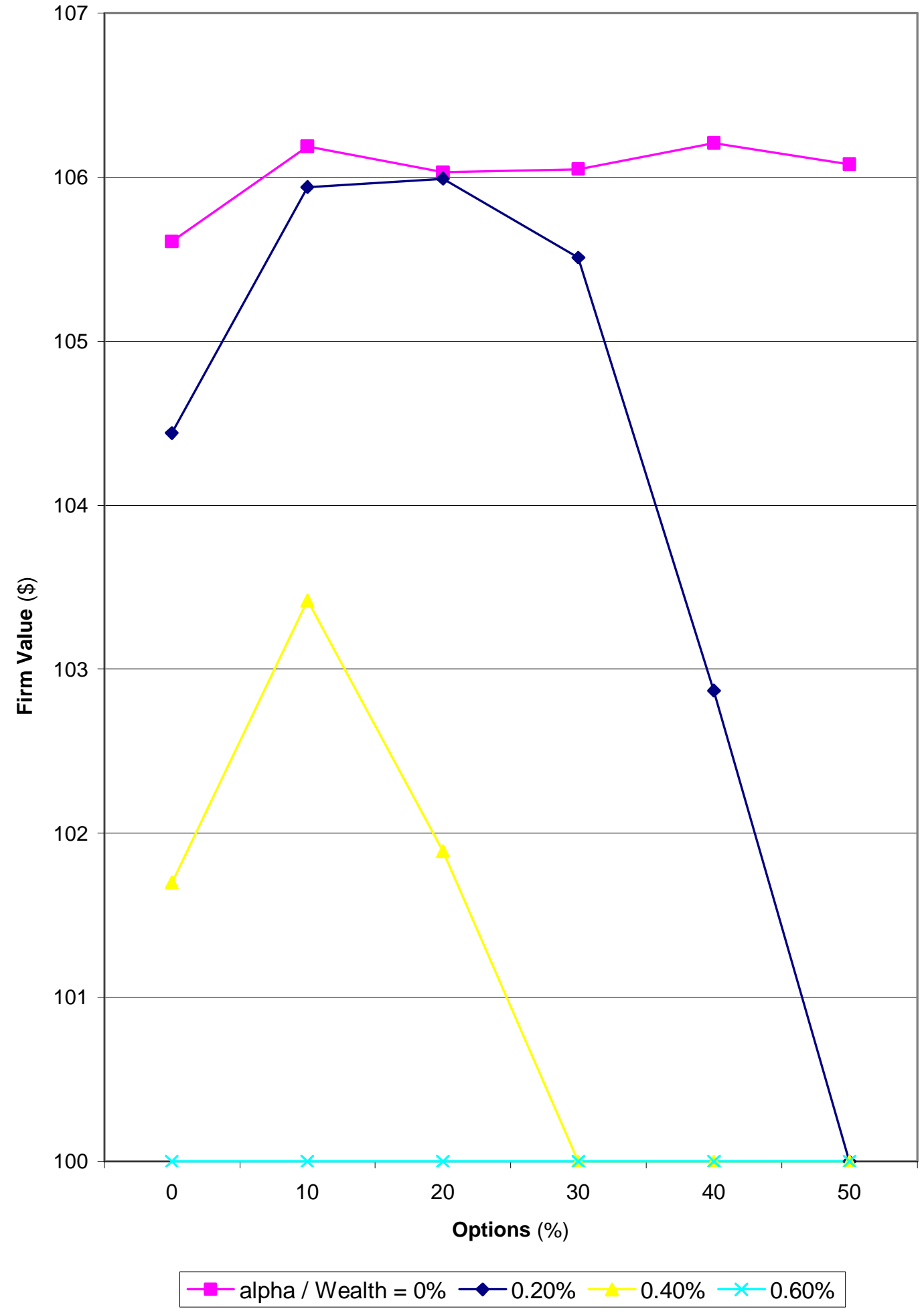


Figure 4

Firm Value as a function of career concerns and mix of wealth Options $=25 \%$; Shares $=(75-$ Cash $) \%$

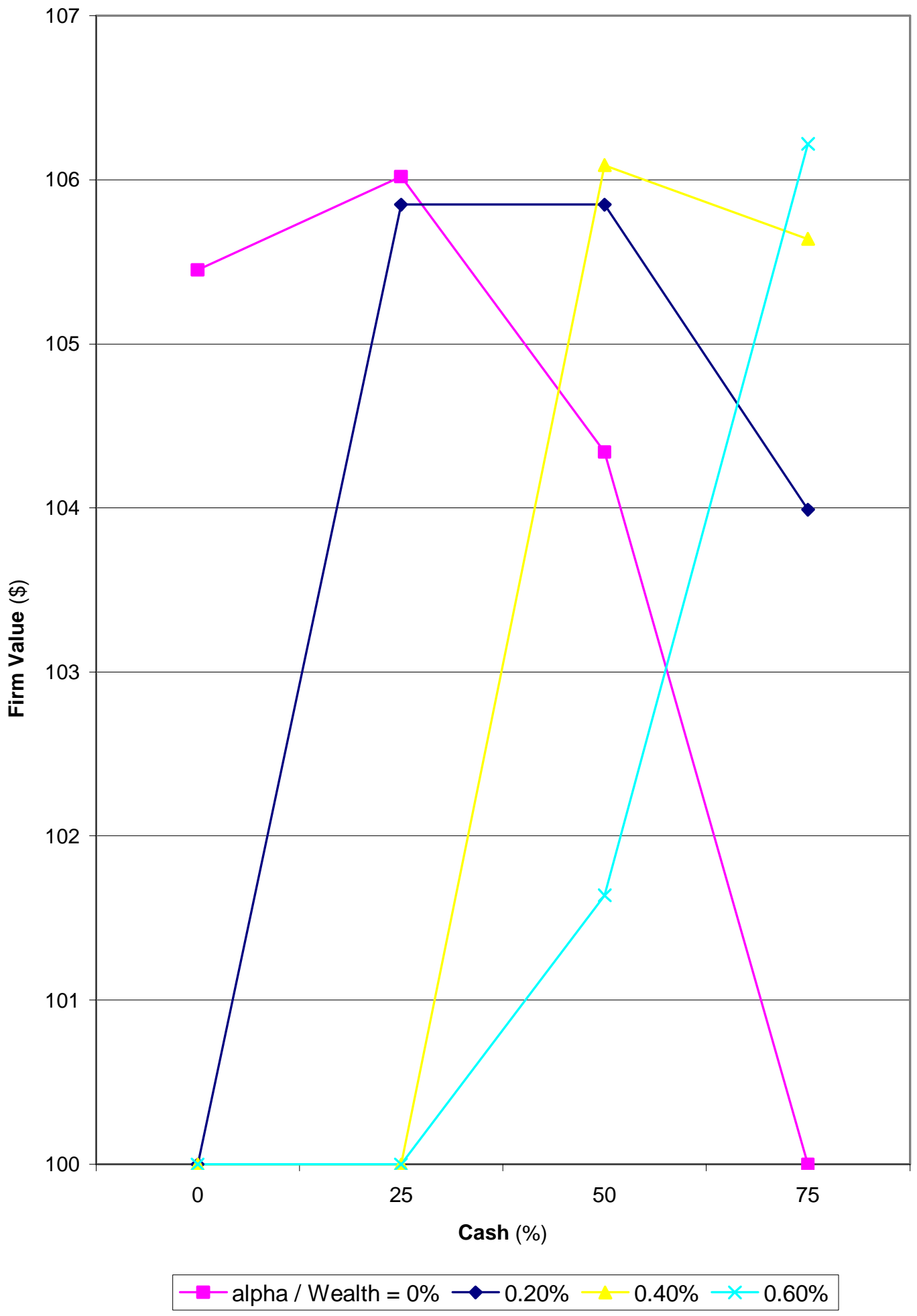


Figure 5

Firm value and pay-for-performance (PFP)

Cash $=75 \%$

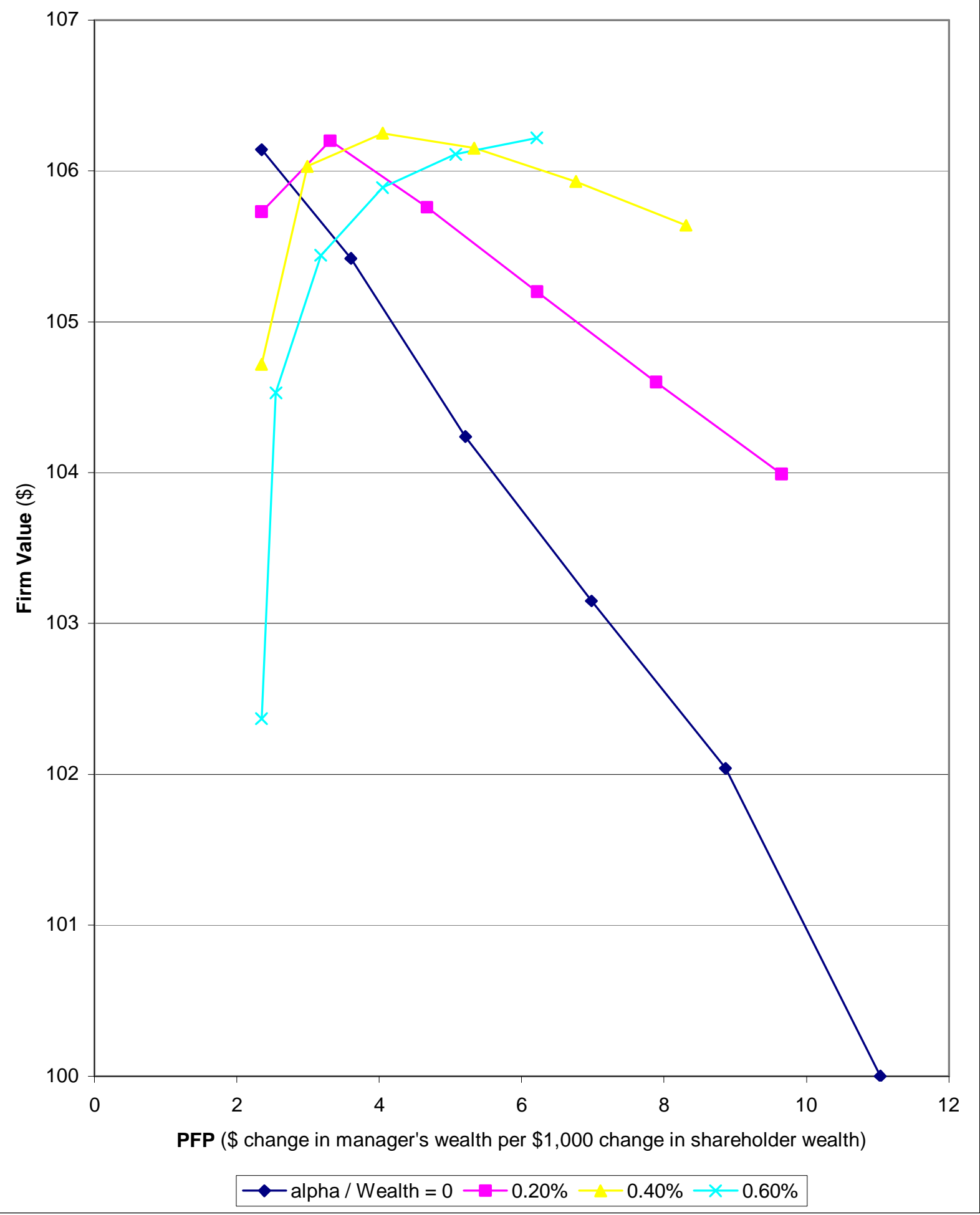


Figure 6

Firm value and pay-for-performance (PFP)

Cash $=50 \%$

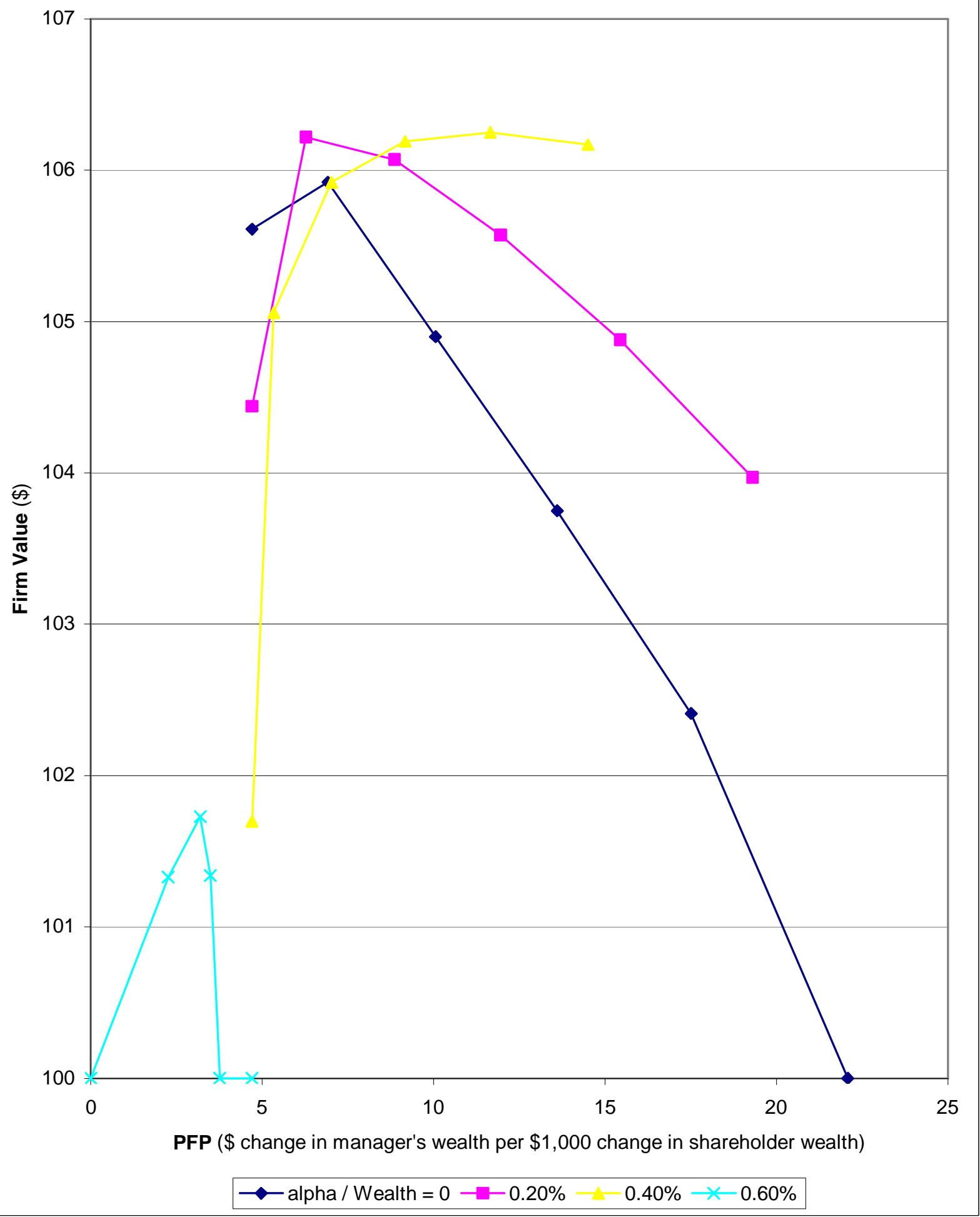


